\title{
Democracy, Liberty and Montesquieu: Constructing Accountable Order in African Conflict States
}

\author{
David K. Leonard*
}

Abstract Without appropriate institutional checks multiparty democracy can rekindle violent conflicts rather than help to resolve them. The absolutism of 'imperial presidents' is at the root of many of Africa's civil wars and the restoration of this institution in post-conflict states will not help them find security for their citizens. Following Montesquieu, I argue that 'liberty', in the form of checks on executive power, must accompany or precede multiparty democracy in post-conflict reconstruction.

\begin{abstract}
1 Introduction
The path out of intra-state violent conflict used to be 'simple' - fighting continued until one party won or a stalemate produced a compromise settlement, so that the way to reconstruction was embedded in the concluding peace. However, such 'simplicity' was based on letting a conflict first run its course, and thus purchased at the cost of prolonged violence and loss of human life and wellbeing. Fortunately, since the end of the Cold War the international community has made the process more 'complicated' in Africa by bringing such violence to a 'premature' pause. Other states, generally under the auspices of the United Nations or the African Union, now are likely to intervene with peacekeeping forces to stop the fighting and will provide aid with political reconstruction. Such 'new generation' peace efforts have been among the factors reducing violent conflict in Africa since its highpoint in the early 1990s (Straus 2012). This mitigation of violence has been a great benefit for human welfare but the newness and complication of the subsequent steps has made 'the best way' to rebuilding order unclear. In this article I wish to explore whether we might do a better job by broadening and reprioritising the terms of reference for reconstruction.
\end{abstract}

Until recently most post-conflict effort in Tropical Africa has followed the path of: (1) an agreement on an interim coalition government between the leaders of the contending forces, (2) Disarmament, Demobilisation and Reintegration (DDR) of the contending armed forces, (3) an election after a defined interval to confirm and legitimate a new government, and (4) the rebuilding of central state capacity, including some degree of Security Sector Reform (SSR). It is now evident that this model was insufficient, for we have seen some of the conflicts reignite after an initial period of peace and in most of the others the reconstruction process has dragged on much longer than expected (Collier 2009).

The articles in this IDS Bulletin on Côte d'Ivoire by Allouche and Zadi Zadi and on the South Kivu Province of Congo by Mushi make it clear that one part of what needs to be added to the reconstruction agenda is (5) patient mediation and resolution of the local conflicts that help to fuel the civil wars and which generally remain when the elite-level bargains are struck at the national level. This point is made as well by Autesserre (2010).

Similarly the articles by Vincent on Sierra Leone, Mushi on Congo, Samantar and Leonard on Somalia (see also Leonard and Samantar 2011), as well as the second, Overview article by myself in this IDS Bulletin all make the point that (6) as there is a double social contract between citizens and their communities and between communities and the state, the reconstruction of

IDS Bulletin Volume 44 Number 1 January 2013 @ 2013 The Author. IDS Bulletin (c) 2013 Institute of Development Studies Published by Blackwell Publishing Ltd, 9600 Garsington Road, Oxford OX4 2DQ, UK and 350 Main Street, Malden, MA 02148, USA 
a legitimate (even if reformed) local government and of its relationship with the centre also are an equally high priority after a civil war.

Finally, I wish to add in this article that (7) none of the foregoing steps will work properly unless the various powers in the reconstituted state check and balance each other, to produce what Montesquieu called 'liberty'. Such a step toward a 'moderated' and more liberal state needs to accompany or even precede democratic elections (3 above). Similarly restoring local order (5 and 6 ) is facilitated by Montesquieu's liberty. To make this argument I first will outline the social context within which democracy and governance are conducted in contemporary Africa. Second, I wish to review the debates about whether democracy is appropriate in a post-conflict situation. I then will discuss insights from Montesquieu, who argues for 'liberty' and a 'moderate[d]' state. In this last step we will be returning to the classical political theories of the era in which the modern democratic state was created in western Europe. The second, Overview article in this IDS Bulletin examined the social contract theorists of this era (as was done even more thoroughly in Leonard and Samantar 2011). Montesquieu took a different 'cut' on the challenges of royal absolutism, but his work came between the social contract contributions of Hobbes and Locke, on the one hand, and that of Rousseau, on the other. His Spirit of the Laws (1949) was highly influential in shaping the constitution of the USA (Madison et al. 1992 [1788]) and in the early stages of the French Revolution.

\section{Elections and conflict \\ 2.1 A dual purpose}

Ideally, democracy should serve two functions in society - representation and conflict resolution. ${ }^{1}$ The most prominent of these and the one that has received the great bulk of scholarly and policy attention has been the first - a mechanism for making government responsive to the expressed interests of the population it serves. But democracy can and does play another role as well - providing an alternative to violent conflict as a means of determining who will rule the state, a mechanism that can become routinised in a society and is less costly to human life and economic growth (Straus 2012).

Elections are not straightforward as tools for conflict resolution, however. They provide a specific time and contest at which the composition of government is to be determined. As a result unless they are very well managed - the social forces underlying a country's most important conflicts are likely to be mobilised to 'fight' the election (note the word). In this way an election can bring to a head the very conflict it is supposed to sort out and thus itself produce violence, even if in a diminished form (Straus 2012).

Recent studies by Paul Collier, Jack Snyder and Roland Paris have demonstrated that elections in post-conflict situations run a high risk of reigniting the conflict they are supposed to resolve. Given the milieu of patronage described below, elections can create an opportunity for political entrepreneurs to advance their careers through extremist appeals to mobilise their ethnic or religious group and such 'out-bidding' can lead to increased violence in society. So although elections are a precipitating rather than an underlying cause of violence in society (a distinction made by Brown 2001), the ability of elections to mobilise extreme opinions that outlast the immediate contest should make us cautious about their conduct when conflict is already present (Mbugua 2006).

Snyder (2000) analyses cases from the 1990s to argue that if democratisation is not to take a disastrous turn into nationalistic conflict it must be preceded by economic development, an established middle-class, a professional media, and a well-functioning state (with the rule of law and an impartial bureaucracy). He also contends that elites who would be displaced by elections must have an alternative to political power that they find acceptable if they are to surrender it without a fight. Prior to the achievement of these conditions he is prepared to accept a mildly authoritarian regime that is moving toward democracy. The bulk of his analysis derives from developments in the former Soviet bloc, although he also considers Rwanda to some extent.

Paris (2004) uses a largely different set of cases than Snyder, but he too concludes that the introduction of democracy will dangerously increase societal conflicts unless the institutional preconditions for its success have been met first. Thus he calls for Institutionalisation Before Elections. By 'institutionalisation' Paris means that an array of pro-democratic organisations, practices, and rules should be in place and valued 
by key actors for their own sake (Selznick 1957; Stinchcombe 1968). As Paris does not favour the establishment of authoritarian regimes as a step out of civil wars, in effect he is calling for an extended period of international stewardship over post-conflict countries, delaying the initial election until reforms in the structures critical to successful democracy are in place and extending supervision for some time afterwards while they gain acceptance. Most of the elements Paris prescribes became standard objectives for United Nations Development Programme (UNDP) postconflict election missions in the twenty-first century (Leonard 2009a; UNDP 2009), save that he would not proceed with elections without evidence that 'moderate' political parties would prevail over those promoting inter-group conflict. Bastian and Luckham (2003), also working from case studies, lend support to this last precondition.

Collier shares the concern of Snyder and Paris that the international community has been too anxious to see elections as a panacea for conflict resolution and has been too quick to exit conflict states after the vote has been conducted.

However his major concern - backed by crossnational econometric evidence - is to persuade donors that post-conflict reconstruction is a lengthy process, requiring at least a decade of sustained effort and assistance (Collier 2007).

\subsection{Sequencing or gradualism in democratisation?}

Should preparation for democracy be consigned to a non-democratic 'care-taker' out of concern over domestic conflict? As Carothers (2007) remarks, 'the record of democratic change since the "third wave" began in 1974 reveals few successful cases of "controlled reforms" leading to democracy'. His point is reinforced for Africa by the constitutional history of Uganda under President Museveni, who insisted that in order to avoid democracy's causing the re-eruption of ethnic conflict, there would have to be a period of controlled transition under his guidance - but who in fact has perpetuated his own brand of enlightened authoritarianism for two decades and fought a long, ethnically based civil war in Uganda's north as well (Griffiths and Katalikawe 2003). One could take an even older historical sweep and note that most of the world's democracies emerged first in periods of civil disorder, not smooth institution-building or careful preparation by authoritarian rulers.
This is not to deny the importance of a suite of institutions and social conditions supporting a democratic society, nor is it to argue for forcing elections on a society that doesn't seem to be asking for them. In Africa, however, the demand for democracy is very high. It enjoys majority levels of popular support in almost all African countries and military regimes are never preferred (Bratton 2007). Very often combatants demand elections as a condition for stopping fighting (e.g. Burundi, Democratic Republic of the Congo, Liberia, Republic of South Africa, Sierra Leone). In contemporary Africa most often there really isn't a choice about whether or not to hold an election. In fact elections are held regularly and manipulated vigorously precisely because they confer a form of legitimacy on executive and legislative authority. Thus in Nigeria it matters to people that their presidents and governors are elected and are not simply appointees of an informal committee of generals. Military authority is widely seen as having failed in Africa and even the military most often wants to see a civilian approbation of leadership, the selection of which it may have influenced.

It is in contexts where elections are difficult but nonetheless popular and necessary that the distinction between 'sequencing' and 'gradualism' is useful. Carothers (2007) writes,

Sequencing is about putting off democracy especially open, competitive elections - until some time in the indefinite future while pursuing state-building and the rule of the law in the meantime. Gradualism is different. It is based on the recognition that authoritarian rule is itself usually a key obstacle to building a well-functioning state and establishing the rule of law. The gradualist approach seeks to find a way for countries where few circumstances favor democratization to take incremental but definite steps toward open political competition while simultaneously pursuing statebuilding and rule-of-law reforms.

Lindberg's work adds support to this tack. His cross-national econometrics suggest that elections in Africa become more democratic the more often they are repeated, even if they are not conducted auspiciously at the start (Lindberg 2006; 2009). When an election is held it sets in process a series of societal changes in organisations (e.g. the rejuvenation of parties), 
behaviour (e.g. politicians who are looking toward electorates when making policy decisions) and attitudes (e.g. citizens who come to expect contested elections) that build momentum toward still further democracy. This finding is reinforced by that of Robert Bates (2008), who finds that in Africa the prospects of militias challenging state order is decreased by elections. ${ }^{2}$ Nonetheless, it is true that both the Lindberg and Bates findings are averages, may be more true in Africa and Eastern Europe than elsewhere, and are not something that is automatically assured (Lindberg 2009). The democratising and conflict-reduction effects of elections also have been achieved in Africa through ongoing domestic and international pressure - and probably the realisation by current power-holders that their interests will be adequately served with less severely antidemocratic measures (Heilbrunn 2007).

Bastian and Luckham (2003) insist that there is no universal design template for democratisation history matters, as does the process of institutionbuilding and the actions of the political actors involved. But the choices are not just (a) quick elections, no institution-building and rapid international exit vs (b) no elections, institutionbuilding and continued international involvement. The options are much more complex than that particularly in sub-Saharan Africa, where so many states are donor-dependent and international involvement in elections has come to be accepted (and is even a part of African Union expectations).

Although it is true that the process of regaining stability after a conflict is sure to be lengthy (and it is false to expect that those in the international community who have intervened to bring the fighting to a close will be able to exit quickly after an election), the demands of African citizens and the dynamics of negotiating the end to civil wars make gradual progress toward elections a frequent necessity. The question is not whether to hold elections but how can the international community help conflict-prone societies hold elections that avoid violence and promote peaceful conflict resolution, despite the acknowledged difficulties?

\section{The social milieu of contemporary African democracy \\ 3.1 A context of patronage}

Throughout Africa (and, indeed, in many other developing countries) voting is largely determined by ethnicity, kinship and neighbourhood. ${ }^{3}$ In rural areas, where all three tend to coincide, the result is that voting at the polling-station level will generally be in favour of one particular candidate, with the decision effectively being a collective one, sometimes enforced by implicit coercion. For example, Barkan et al. (2006) found in Kenya that the average vote for the winning candidate for parliament in 1997 was 65 per cent, even though there was an average of 4.4 candidates. At polling station level this pattern of local consensus would be even more obvious. (Only in the major urban areas is the coincidence of family and neighbourhood broken. Although kinship and rural ties will still be influential for all but secondgeneration urban elites, adherence to them will not be as noticeable in city polling stations.)

This ascriptive voting behaviour is neither atavistic nor irrational. African states provide no reliable, formal systems of social security and individuals can rely only on their kin and neighbours for assistance. This not only strengthens the ties of ascriptive solidarity but also makes it rational for one to want state benefits to reach members of one's own social group, even if one does not get them oneself - for those who receive them might then be in a position to help in the future.

Not only does the above social dynamic lead voters to seek out patronage goods for their communities, it also makes it relatively easy for political candidates to see whether the community around a particular polling station has been faithful to its part of the clientage bargain and has delivered - en masse - the expected votes. Visibility, and hence enforceability, make patron-client relations efficient and even more attractive (Kitshelt and Wilkenson 2007). Thus, even if achievementoriented, policy-based political competition might produce better results for the country as a whole, the individual politician, community and voter will find patron-client political ties rational.

Politicians who fail to provide jobs, infrastructure and other elements of patronage will disappoint their electorate and be vulnerable to challenge in the next election - either from the opposition (most often in an urban area) or another faction of the party (in most of the countryside). The temptation to be corrupt and profligate with the 
public purse in order to gain patronage for personally targeted distribution (with some personal wealth on the side) is overwhelming.

Of course an elected office holder could (and should) provide constituency service without being corrupt. Constituency service is a benefit provided to all individuals of a certain place or category, regardless of their personal votes. Patronage, on the other hand, is visibly targeted only to those who are supporting the politician, so that the benefit is a reward for political backing. ${ }^{4}$ The boundaries between constituency service and patronage overlap, but the end points of the continuum they describe are clearly different. Patronage is politically more efficient than constituency service and is much more prone to corruption.

\subsection{Strong presidents}

African states are weak in the face of very strong societies (Migdal 1988). As Aristide Zolberg noted 40 years ago, this makes nervous national politicians construct governmental systems that are as strong as possible - hence the long period of one-party rule on the continent and the persistence even today of very strong presidencies (Zolberg 1966).

The resulting problem is that the stakes for winning or losing the presidency become inordinately high. A key dimension of the violence that frequently surrounds presidential elections in Africa is the extreme concentration of authority in the presidency. Such unchecked power is often described as an 'imperial presidency'. It parallels the 'royal absolutism' of early modern Europe, which Napoleon was able to reproduce by replacing 'the divine right of kings' with plebiscitary democracy. We will see that the resulting threat to liberty is precisely the problem Montesquieu addresses.

Post-conflict states are even weaker in facing strong societies than they were at independence. The temptation of domestic and international leaders alike then is to assist in rebuilding a strong presidency with security and civil services that are wholly responsive to its direction. But the conflicts from which these states are escaping generally were exacerbated, if not caused, by precisely such 'imperial presidents' and the reconstruction of durable peace is made harder by their recreation.

\subsection{Parliaments of rural ambassadors}

When patron-clientage is combined with a strong presidency the legislature becomes a collection of (largely rural) ambassadors petitioning for patronage goods they can distribute to their constituencies (or turn into personal wealth for themselves, which, in turn, can be used to make them generous 'big men' at home). For Members of Parliament who operate in these circumstances, deliberating on public policy, passing laws, and holding government accountable, are minor activities when seen from the point of view of re-election. To some extent the same can be said of first-past-the-post constituency legislators everywhere. But the strength of society and the presidency in Africa makes the tendency much stronger.

It is difficult in most of Africa to produce competitive political parties based on public policy differences rather than the distribution of patronage - at least until the issues around service provision shift from their physical presence in particular constituencies to their general quality and until income from oil or international aid is no longer the most important source of income for the elite.

\section{Montesquieu and liberty}

When the usual answer to a question is unsuccessful and the alternatives are confused, the difficulty often is that the problem is being misconceived - that the question needs to be posed in a different way. To do so, I think it is useful to ask how Montesquieu ${ }^{5}$ would have looked at and analysed the problems of postconflict reconstruction and the violence often provoked by multiparty elections. He saw the basic challenge of his era not as one of 'democracy' but instead of 'liberty'. By this he meant that the fundamental problem was one of ever-increasing absolutism, which he saw as a threat to 'liberty' as he understood it.

Of course Montesquieu never recommended principles of government for sub-Saharan Africa. Although he had the largest private library in Europe of his epoch, ${ }^{6}$ it is very unlikely that he had even a single book on the region. But over the course of the last 30 years the world has debated the best means of improving governance in Africa. The regimes most often prescribed include democracy and free markets. Montesquieu was the greatest eighteenth 
century French advocate against mercantilism and for the free market. ${ }^{7}$ More important, his ideas on the ideal form of government were based on the then current practice in England and had a great influence on the constitutions adopted by France and the USA after their revolutions. These three states are the most frequent model for new democracies in Africa and Montesquieu himself invites the reader to apply his ideas beyond the cases he analysed (Montesquieu 1995 [1748], 1949 Bk. XI, Chap. 20.) One could well argue that Montesquieu is partly responsible for causing 'liberal democracy' to be 'liberal'.

'Democracy' is not necessarily 'liberal'. Greek democracy was rooted in the community and had no conception of individual rights that could stand against the collective. Rousseau gave the community and its 'general will' much more emphasis than Hobbes and Locke, who had focused on individuals and their rights. Thus Rousseau was the social contract theorist who was used most often in support of plebiscitary democracy and the imposition of 'social rights' over 'individual liberties'. One might think then that liberal democracy is ill-suited to Africa, for we argued in the second, Overview article in this IDS Bulletin that the primary social contract in Africa is between the individual and his or her community and that the social contract with the state is mediated by the community one. Unlike ancient Greece or Rousseau's Geneva, however, the community and the state are not one in Africa (Parekh 1993). The 'liberal' principle that subordinates have rights and liberties which deserve protection through checks on the state in practice serves the multi-ethnic and multireligious communities of Africa better than the collectivist, plebiscitary ideals of independenceera African nationalism did. Hence

Montesquieu's thought and liberal democracy are relevant to contemporary Africa, despite their origins in a quite different cultural milieu.

\subsection{Montesquieu's understanding of liberty}

It might be thought ironic that Montesquieu is considered one of the founding philosophers of democracy, for he saw an elected assembly as only one component in the reform of monarchy. For Montesquieu the most valuable principle was 'liberty'. (Note that the French Revolution was conducted in the name of 'liberty, equality and fraternity', not 'democracy'.)

\section{In De L'Esprit des Lois [The Spirit of the Laws]}

Montesquieu speaks of two forms of liberty constitutional and individual. Both are construed in legal terms. Of the constitutional, he writes,

Liberty is a right of doing whatever the laws permit, and if a citizen could do what they forbid he would be no longer possessed of liberty, because all his fellow-citizens would have the same power [XI, 3]... Political liberty is to be found only in moderate[d] governments; and even in those it is not always found. It is there only when there is no abuse of power. But constant experience shows us that every man invested with power is apt to abuse it... To prevent this abuse, it is necessary from the very nature of things that power should be a check to power [XI, 4] (Montesquieu 1995 [1748]).

On individual liberty, he says,

It is not sufficient to have treated political liberty in relation to the constitution; we must examine it likewise in the relation it bears to the [citizen] subject [XII, 1]... Political liberty consists in security... This security is never more dangerously attacked than in public or private accusations. It is therefore on the goodness of criminal laws that the liberty of the [citizen] subject principally depends... When the subject has no fence to secure his innocence, he has none for his liberty [XII, 2] (ibid.).

Montesquieu's personal experience had made him very sensitive to the abuse of power of the French monarchy. He was a presiding judge in his region - président à moriter du Parlement de Bordeaux - and hence a guardian of the law. The various parlements of France were aristocratic regional courts and often were in conflict with the ministers of the king, hence his view that the powers of the king ought to be moderated by the powers of judges such as himself. Further, his wife came from a Calvinist family; thus he thought that one should be imprisoned only for acts, not for one's beliefs or the expression of one's thoughts, i.e. that one should have liberty of religion and speech. Finally, Montesquieu's estates produced wine and he had an active interest in its sale and export. Hence he understood well the damage done to commerce by an arbitrary and rapacious executive. He worried less about whether a government was a monarchy 
or a democracy than that it did not become despotic. Above all he wanted government that was moderate[d] and subject to law.

\subsection{New possibilities for liberty in Africa}

From the above analysis one can see that Montesquieu would say that contemporary African states are despotic and that they suffer the consequences of a lack of liberty. In addition Montesquieu would recommend that the problem of liberty weighs more heavily than that of democracy - what would one gain if the president were freely elected but despotic? It is more important that the powers of presidents be moderated, he would say. And if there is a state with constitutional liberty that violates the rights of man and thus deprives citizens of individual liberty, one would not gain much, in his view. For life is not good if it lacks "security", protection against false criminal accusations that could gravely threaten physical liberty, one's property, honour or even one's life' (Gressaye 1955).

Thus Montesquieu clearly would recommend 'moderate' governments for Africa. He would highlight the conflicts and dysfunctions that absolutist 'imperial presidents' have created on the continent (just as they did in the Europe of his era) and would strongly argue against a neglect of liberty in the reconstruction of order or democracy in post-conflict states. By 'moderate' he is not speaking in The Spirit of the Laws of a conservative regime but of one in which each power is 'moderated' by the check of another power [XI, 4]. This idea is not completely original to Montesquieu; he himself cites classical and humanist writers on the experience of the Roman Republic with a mixed government [XI, 12-19]. Cicero and the other classical authorities had not discussed this practice from the point of view of one power checking another. But Machiavelli gave them that interpretation in his Discours and we know that Montesquieu had read this controversial author (even if he was wise enough not to cite him) (Skinner 2000).

The closest thing to an African president in a one-party state is a king. Montesquieu believed that monarchy could be limited by several paths - by religion and the principle of honour (i.e. by one of the fundamental interests of the aristocracy) [III, 10] or by a popularly elected legislature and an aristocratic judiciary (as in England and the Roman Republic) [VIII].
As Montesquieu recognised in his treatment of the Roman army, however, a power will not be limited unless it is stopped by another substantive (rather than just constitutional) power [XI, 17]. When the first constitutions were written for the newly independent African states in the $1960 \mathrm{~s}$, an attempt was made to create checks on the executive by the legislature, the judiciary and local governments. But colonial practice had been completely centralised on the executive and the other institutions that then were newly expected to check it had little real power. ${ }^{8}$ For example, the independence constitution of Kenya stipulated that there would be strong regional governments, but when the extremely popular President Kenyatta ordered the civil service to obey his orders and not those of the regional governments, all submitted.

Thus it is important to ask, 'Are there now alternative institutions in contemporary Africa that have sufficient real power to challenge a president if they are granted constitutional authority to do so?' Let us start by enumerating the several countervailing forces that can challenge absolutism today:

i In observing the democratisation movements in Africa since 1990 one sees that attorneys and religious leaders played a very prominent role. The ideology of most of the new states has been secular and thus it is not easy to give constitutionally 'established' positions to the clergy or budgetary support to the core functions of the churches. But precisely this lack of state finance has made it difficult to co-opt the clergy, and their power with their followers continues to grow. In the same manner most attorneys earn their living outside the state, representing their clients against other private citizens and firms or against the state itself. Thus their revenues also are independent of the state and it is hard for a president to co-opt the legal profession as a whole. Plus attorneys have knowledge of the law and thus possess an important tool in challenging the state.

ii African civil society is no longer the same as it was 50 years ago at independence. The imposition of structural reforms on African economies in the 1980s and 1990s reduced the impact of the state on businessmen, and the finance donors have continued to provide to indigenous non-governmental organisations 
(NGOs) also have created a new space in which local elites can secure their welfare without dependence on government.

iii At independence most analysts had seen trade unions as powerful. But there was too much unemployment and it was easy for the first generation of African presidents to break their strikes and co-opt their leaders with government positions. The unions remain weak but due to the collapse of state revenues their leaders are not receiving the same patronage as they once enjoyed. Thus trade unions are a bit more of a check on presidents than they had been.

iv Regional political leaders have always been strong in Africa. Except in the cities, African ethnic groups have had a territorial base, so that the power of geography and ethnicity are unified. At the time of independence the greatest fear of presidents was that their countries could be dismembered, so that they devoted great energy to co-opting and undermining regional political leaders. However, most secessionist movements in Africa have failed and those that have shown success, such as South Sudan, Somaliland and now Northern Mali, have done so precisely because of central antagonism to their regional needs. Legitimate regional governments are not quite as threatening as they once were and Nigeria, the Democratic Republic of the Congo and Kenya have embraced them as a partial solution to domestic violent conflict. These regional governments today have the ability to offer a check on 'imperial presidents' if their authority is constitutionally recognised.

v More broadly, the plurality of ethnic groups, underpinned by primary social contracts at the community level, has the potential to offer not only order but also a check on 'imperial presidents'.

vi Finally and obviously there is the army, for Africa has experienced multiple coups d'etat in the $50+$ years since independence (even if their frequency and legitimacy has now diminished somewhat). Montesquieu wrote that 'An elected monarchy, like that of Rome, necessarily supposes a powerful aristocratic body to support it, without which it changes immediately into a tyranny...' [XI, 13]. In other words, the army must not be just an extension of the executive or an alternative to it, but serve as a check on it and have its own values as well. But just as Rome was turned from a democratic into an imperial state when its army officers became the source of executive power rather than a check on it, so coups d'etat in Africa produced tyranny. Without coups, however, African army officers are the equivalent of the medieval nobility in contemporary Africa. In addition over the last decade they and their troops have been trained for and engaged in international peacekeeping missions. Thus they not only have the power to check the executive but new socialisation in protecting human rights.

All this suggests that there are some sources of real power that are beyond the full control of contemporary African presidents. How might they be institutionalised and given greater constitutional and legal leverage? If one were to create in each country a senate whose members were elected by professions, churches, business and civic associations, regional assemblies, and the officers and enlisted men and women in the security services, it is quite possible that they would be able to provide the kind of check that the House of Lords played in England at the time of Montesquieu. In the democratic movement of the 1990s in Francophone Africa, there was much use of the institution of a 'national convention' (copied from the French Revolution) - an institution of elites chosen by each civil society association (and not by citizens at large). A senate could be built on this foundation and on the high esteem that 'intellectuals' receive from their fellow citizens in Africa. Such senates would be able to challenge gross abuse of power by presidents, even if they only had the power to block laws and regulations (but, following the English model, not expenses) for a year. Unlike the parallel popularly elected national assembly, whose focus is the proportionate representation of individual citizens, senates would give a voice to all the constituent groups in the system. It would help minorities feel that they can be heard but also would give powerful elite groups a place where their views and demands could be seen publicly and therefore subject to honest bargaining.

At first it might seem strange to give such constitutional legitimation to some of the groups I have listed above. African armed forces, for example, have been a greater force for abuse of power than for democratisation or liberty in the 
years since independence. But representation of the armed forces would reflect the reality of their power in African political systems and there are considerable advantages that would come from having their views and grievances out in the open so that bargaining was facilitated. Further, by treating the armed forces as but one of several important social forces in a constitutional representative body, the voice of the other groups would be strengthened and the legislative dialogue would moderate both the president and the army.

To go still further on the lines suggested by Montesquieu, one might have a committee elected by the senators who are attorneys to serve as the final judicial court of appeal (as is the case in England) and also that each new judge nominated by the president must be confirmed by this committee (as happens in the USA). The supervision of the judiciary by a base outside the immediate influence of the president or the popularly elected assembly would give the legal system much greater independence. In this way, if the legislative role of the senate would create a 'moderate[d]' government at the level of the constitution and the government, the surveillance of the courts by the members of the legal profession sitting in the senate would assure individual liberty.

There have been promising experiments with other constitutionally protected checks on the government of the day. Genuinely independent electoral commissions are widely advocated (even if the political pressures to sway them are often hard to resist). Similarly, Sierra Leone has a Political Parties Registration Commission and an Independent Media Commission. Kenya has a Truth Justice and Reconciliation Commission, a Human Rights Commission, and a National Cohesion and Integration Commission. None of these have changed everything overnight. But with the support of donors and local professionals - both important sources of real power independent of executive control - they have made some encouraging inroads (Leonard et al. 2009a, 2009b).

Finally, we can add the checks provided by regional and local governments (including modernised 'traditional' ones). Political decentralisation ('devolution') rarely produces improved service delivery for the poor (Crook and Sverisson 2003). And 'traditional' institutions often are in need of significant reform (Crook et al. 2010). When adequately resourced, however, they lower the stakes in national elections, provide a check on presidential authority, and greatly assist with the mediation and resolution of the local disputes that so often fuel national-level conflicts.

Of course we know from the experience of independence that the insertion of clauses in a constitution by itself achieves next to nothing. It cannot create counter-powers, but it can channel, regularise and legitimise existing ones. The point is to give constitutional authority to forces in civil society that have gained real political significance in the last quarter of a century and have interests and values that would incline them to using that political power to check an 'imperial president'. The key to a 'moderate[d]' government and thus to liberty is to connect constitutional checks and balances to real political bases that will support them.

When the above ideas emerged from the pen of Montesquieu they may have had a medieval aspect, with their three estates and the guilds, but the democratic institutions of Europe came from precisely these roots. They first emerged there in a time when the larger number of the population were peasants. Perhaps they therefore also are a 'fit' for Tropical African states, where most of the citizenry also are peasants. Such institutions cannot replace electoral democracy, but they can lead to liberty whether full democracy exists or not.

\section{Conclusions: liberty as a path to democracy and conflict resolution}

Where should democratisation stand among the priority tasks for reconstructing human security and order in African states emerging from violent domestic conflict? Elections cannot be avoided, for they virtually always are demanded by elites and ordinary citizens alike, are central to legitimating new governments, and affirm the popular principles (sometimes in the face of reality) that government is a civilian (rather than military) responsibility and is accountable to the citizenry.

But when elections are conducted without the support of other democratic institutions they can provoke violent conflict rather than offering an 
alternative to it. Donors and the United Nations have had to devote considerable resources to elections in states undergoing reconstruction and even those have not always been 'free and fair'. Among the institutions that can support democracy, however, are those that deliver 'liberty' - a genuinely independent judiciary and other countervailing powers to the presidency (which make winning it less desperate and provide a venue for contesting election irregularities). Liberty has its own benefits, even in the absence of full democracy. For example, we know that the arbitrary and capricious administration of the law interferes with economic growth (North 1990).

In reconstructing post-conflict states more attention needs to be paid to the social contracts which provide governance and order at the base of the political system and to resolving local level disputes over land and water (Straus 2012). Multiparty elections also can reignite national conflicts which they ought to help resolve if they are not conducted in an appropriate institutional context. And multiple bases of authority help with these challenges as well.

It is more feasible to see the challenge of postconflict reconstruction as one of creating real checks on 'imperial presidents' than one of breaking patrimonialism and creating 'free and fair' electoral contests between competing political parties, particularly when the results are

\section{Notes}

* I am grateful to Robin Luckham, Anna Schmidt and Scott Straus for comments they made on an earlier version of this article.

1 The following 12 paragraphs are based on Leonard (2010). They are reprinted with the permission of the publisher.

2 Bates does find that multiparty systems are more likely to create challenges to order but the effects of elections to the contrary are stronger.

3 The next nine paragraphs are based on Leonard (2009b). They are used here by permission of the Electoral Institute for Sustainable Democracy in Africa (EISA), the publisher.

4 The fact that patronage works best when it is a 'private good' or a community ('club') one 'winner take all'. Patronage and ethnically based electoral competition are both still deeply rooted in Tropical African societies. But as we noted above, the social, economic and international bases of local elites have diversified and strengthened changes in Africa over the last quarter of a century in ways that make the survival of the institutions of liberty more likely if they can first be given constitutional authority and donor support. At independence new rulers fairly easily got the voter support needed to sweep aside constitutions that restricted their power. However, as is illustrated by the electoral defeats in the last decade of President Wade in Senegal and President Kibaki in Kenya when they proposed constitutions more advantageous to themselves, citizens in many countries on the continent are now more discerning. Not only might prime ministers and bicameral legislatures now survive and provide checking roles, but electoral commissions are gradually gaining in independence and new, constitutionally entrenched bodies that protect key components of democracy have been created in some countries, where they are beginning to show influence. At the moment more of the energy and resources of the international community go to the mechanics of making post-conflict elections 'free and fair' than go to the creation and consolidation of the institutions of liberty - from the judiciary, through local governments, senates and independent commissions. The order of those priorities needs to be reversed.

and the damage this does to the larger 'public goods' component of most valuable public policy is well analysed in Bates (1981).

5 Montesquieu's full name was Charles Louis de Secondat, Baron of Brède and de Montesquieu.

6 The opinion in September 2004 of the guide at the Château de la Brède.

7 The view of John Maynard Keynes as reported in Juppe (1999).

8 Montesquieu foresaw this consequence of European colonialism when he wrote that 'A republic that conquers another state can scarcely communicate its form of government to it and govern the conquered according to its own constitution'. 


\section{References}

Autesserre, S. (2010) The Trouble with the Congo: Local Violence and the Failure of International Peacebuilding, Cambridge: Cambridge University Press

Barkan, J.D.; Densham, P.J. and Rushton, G. (2006) 'Space Matters: Designing Better Electoral Systems for Emerging Democracies', American Journal of Political Science 50.4: 926-39

Bastian, S. and Luckham, R. (eds) (2003) Can Democracy Be Designed? The Politics of Institutional Choice in Conflict-torn Societies, London: Zed Books

Bates, R. (2008) 'Probing the Sources of Political Order', in S.N. Kalyvas, I. Shapiro and T Maoud (eds), Order, Conflcit and Violence, Cambridge: Cambridge University Press: 17-42

Bates, R.H. (1981) Markets and States in Tropical Africa: The Political Basis of Agricultural Policies, Berkeley: University of California Press

Bratton, M. (2007) 'Formal versus Informal Institutions in Africa', Journal of Democracy 18.3: 96-110

Brown, M. (2001) 'The Causes of Internal Conflict: An Overview', in M.E. Brown, O.R. Cole, S.M. Lynn-Jones and S.E. Miller (eds), Nationalism and Ethnic Conflict, rev. edn, Cambridge MA: MIT Press: 3-25

Carothers, T. (2007) 'Misunderstanding Gradualism', Journal of Democracy 18.3: 18-22

Collier, P. (2009) Wars, Guns and Votes: Democracy in Dangerous Places, London: The Bodley Head

Collier, P. (2007) The Bottom Billion: Why the Poorest Countries are Failing and What can be Done About It, Oxford: Oxford University Press

Crook, R. and Sverisson, A.S. (2003) 'Does Decentralization Contribute to Poverty Reduction', in P.M. Houtzager and M. Moore (eds), Changing Paths: International Development and the New Politics of Inclusion, Ann Arbor: University of Michigan Press

Crook, R.C.; Asante, K. and Brobbey, V. (2010) Popular Concepts of Justice and Fairness in Ghana: Testing the Legitimacy of New or Hybrid Forms of State Justice, London: Overseas Development Institute

Gressaye, J.B.d.1. (1955) 'Commentaire', in J.B.d.l. Gressaye (ed.), Montesquieu: De L'Esprit des Loix (Vol II), Paris: Société Les Belles Lettres

Griffiths, A. and Katalikawe, J. (2003) 'The Reformulation of Ugandan Democracy', in S. Bastian and R. Luckham (eds), Can Democracy be Designed? The Politics of Institutional
Choice in Conflict-torn Societies, London: Zed Books: 93-119

Heilbrunn, J.R. (2007) 'Book Review: Lindberg (2006) Democracy and Elections in Africa', Comparative Political Studies 40.9: 1138-41

Juppe, A. (1999) Montesquieu: Le Moderne, Paris: Perrin/Grasset

Kitshelt, H. and Wilkenson S.I. (eds) (2007) Patrons, Clients and Policies: Patterns of Democratic Accountability and Political Competition, Cambridge: Cambridge University Press

Leonard, D.K. (2010) 'What's Needed for an African Election to Help Resolve Rather Than Cause Conflicts?', in K. Matlosa, G. Khadiagala and V. Shale (eds), When Elephants Fight: Preventing and Resolving ElectionRelated Conflicts in Africa, Johannesburg: Electoral Institute for the Sustainability of Democracy in Africa

Leonard, D.K. (2009a) 'Elections and Conflict in Africa: An Introduction', Journal of African Elections 8.1: 1-13

Leonard, D.K. (2009b) 'Special Issue on Elections and Conflict in Africa', Journal of African Elections 8.1

Leonard, D.K. and Samantar, M.S. (2011) 'What Does the Somali Experience Teach Us about the Social Contract and the State?', Development and Change 42.2: 559-84

Leonard, D.K., Owuor, F.O. and George, K. (2009a) 'The Political and Institutional Context of the 2007 Kenyan Elections and Reforms Needed for the Future', Journal of African Elections 8.1: 71-107

Leonard, D.K., Pitso, T. and Schmidt, A. (2009b) 'The Political Economy of Democratisation in Sierra Leone: Reflections on the Elections of 2007 and 2008', Journal of African Elections 8.1: 49-70

Lindberg, S.I. (ed.) (2009) Democratization by Elections: A New Mode of Transition, Baltimore: Johns Hopkins University Press

Lindberg, S.I. (2006) Democracy and Elections in Africa, Baltimore: Johns Hopkins University Press

Madison, J.; Jay, J. and Hamilton, A. (1992 [1788]) The Federalist Papers, Lisle IL: Benedictine College

Mbugua, K. (2006) 'Resolution and Transformation of Election Related Conflicts in Africa', Journal of African Elections 5.1: 22-35

Migdal, J. (1988) Strong Societies and Weak States: State-Society Relations and State Capabilities in the Third World, Princeton: Princeton University Press 
Montesquieu, B.d. (1995 [1748]) L'Esprit des Lois (Vol 1), Paris: Gallimard

Montesquieu, B.d. (1949) The Spirit of the Laws (trans. by T. Nugent), New York: Hafner Publishing Co.

North, D. (1990) Institutions, Institutional Change, and Economic Performance, New York: Cambridge University Press

Parekh, B. (1993) 'The Cultural Particularity of Liberal Democracy', in D. Held (ed.), Prospects for Democracy: North, South, East, West, Cambridge: Polity Press: 156-76

Paris, R. (2004) At War's End: Building Peace After Civil Conflict, Cambridge: Cambridge University Press

Selznick, P. (1957) Leadership in Administration, New York: Harper and Row
Skinner, Q. (2000) Machiavelli: A Very Short Introduction, Oxford: Oxford University Press Snyder, J. (2000) From Voting to Violence: Democratization and Nationalist Conflict, New York: W.W. Norton

Stinchcombe, A. (1968) Constructing Social Theories, New York: Harcourt, Brace and World Straus, S. (2012) 'Wars Do End! Changing Patterns of Political Violence in Sub-Saharan Africa', African Affairs 111.443: 179-201 UNDP (2009) Elections and Conflict Prevention: A Guide to Analysis, Planning and Programming, New York: United Nations Development Programme

Zolberg, A.R. (1966) Creating Political Order: The Party-States of West Africa, Chicago: Rand McNally 